\title{
Mushegyan S.V., Semenova S.N. \\ Legal regulation of land relations in the Kuban region in the second half of the XIXth century
}

Kuban State University

(Russia, Krasnodar)

doi 10.18411/gq-31-07-2020-12

idsp sciencerussia-31-07-2020-12

\section{Abstract}

This article is devoted to the study of the ownership rights of the owner and nonowner of the Kuban territory's land. This is a common property of land relations of the studied period. Actual ownership acted as a prerequisite for the owner's of the land use, both in the Kuban region and beyond its borders in the Russian Empire. The use of a land plot facilitates the implementation of the power of disposition - the power containing the main difference between the owner and the non-owner.

Key-words: possessions, owner, the Kuban region, land use, Cossack villages (stanitsas), history, law.

\section{Аннотация}

Данная статья посвящается изучению вопроса о правах владения собственника и несобственника на землю на Кубани, так как это является распространенным свойством земельных отношений рассматриваемого периода. Для собственника земли, как на Кубани, так и за ее пределами в Российской Империи, фактическое владение выступало как предпосылка пользования. Пользование земельным участком облегчает реализацию правомочия распоряжения - правомочия, заключающего в себе основное отличие собственника от несобственника.

Ключевые слова: владения, собственник, Кубань, землепользование, казачьи станицы, история, право.

The landowner who uses the land, in the desire to possess actual ownership of the land is legitimate being a participant in relations who seeks to protect the acquired land rights to the maximum state. The presence of actual ownership allows a land user to retain his right to relations on the land use when changing the owner of the land.

Thus, land ownership occupies a central place not only in the powers of the land owner, but also among persons who have other property rights to the land.

Land ownership, unconnected with the right of ownership, was characteristic of nonresident land ownership during the period under our survey in the Kuban region. The history and geography of the emergence of nonresident land ownership shows that it appeared after the end of the Caucasian War in the Kuban region and the annexation of the so-called "Zakubanie" territory.

The entire right bank of the Kuban river was built up by Cossack villages (stanitsas) and farms (khutors). Only in the Yeisk department there was nonresident land use that appeared in 1852. In other departments nonresident land ownership appeared 15-20 years later.

The emergence of nonresident land use department dates back to 1867 in the Yekaterinodar. By the order of the Caucasian governor of December 16, 1867, the Grigoryevskaya settlement was formed of state lands. Another soldier's settlement, UstLabinsk, was formed of the Cossack lands of the former Caucasian Linear Army in 1873. Several more settlements were formed in this department: Bezymyannoye, Pyatigorskoe, Staroobryadcheskoe, Khatype and Shabanovskoe until 1898. 
The mentioned settlements were located in the foothill zone and were inhabited by immigrants from the inner provinces of Russia and former Turkish citizens: Moldovans, Poles, Estonians, Greeks, Armenians and Russians.

Peasant nonresident land ownership appeared on privately owned lands that did not belong to either the army or the state. It could appear only after the end of the war in the Caucasus in the late 60 s - early 70 s of the XIXth century. German colonists referred to the first category of owners in the Crimean department in the Kuban region.

It follows that land rights were acquired by nonresident when settling the annexed lands and building the new settlements studied in our historical work. Immigrants received tenure rights only in rare cases involving ownership. That is why the prevailing legal procedure for protecting land ownership, which was in force at that time, is especially interesting for the research. Numerous disputes in land use are actual and important in the possession of such a complex thing as a land, which cannot be created by a man.

At the same time there was a historically developed land tenure of the Circassian and Karachai populations simultaneously with the established Cossack land tenure, and subsequently created nonresident land tenure, in the territory of the formed Kuban region [3, P. 112].

Throughout the XIXth century the state power considered all the possibilities of legal regulation of relations referred to land use of the Circassians and Karachais. So, Karachais and Balkars were granted the right to use grazing land and forest land by decree of May 21, 1829. In addition, an excess land was allowed to be leased by law [2, P. 227-228; 4, P. 1961].

In the second half of the nineteenth century, the fate of the Russian state was fundamentally changed by reforms on free peasants from personal dependence. By the way it led to a reform of the entire social and living order of society, including land ownership.

According to the issued Decree of Alexander II of November 19, 1860 the Black Sea Cossacks and the first six regiments of the Caucasian Linear Army became known as the Kuban Cossack Army.

The territory of the Cossack army became a part of the Kuban region. The title of punishment ataman (Cossack chieftain) was combined with the post of the chief of the Kuban region. Cossacks began to obey administrative and judicial matters to the general regional institutions. For military and economic matters they retained special military institutions: headquarters, military economic management, atamans of military departments.

Some laws defining the land rights of the Kuban army as a legal entity were adopted, on the one hand, and its individual members, on the other after the formation of the Kuban Cossack army in 1860.

The Kuban army was given the royal lands on June 24, 1861. The lands were subject to settlement by hunter-immigrants, and in case of their shortage - by a lot and according to public village agreements [6].

"Regulation on the Settlement of the Foothills of the Western Part of the Caucasus Range by the Kuban Cossacks and Other Immigrants from Russia" was suggested and approved on May 10, 1862 as the consequence.

With the simultaneous development of trade, the Regulation of 1862 laid the foundation for the development of industry in the Kuban region. So, the Regulation stated: "For the development of industry, it is allowed for merchants, manufacturers and other industrialists, with the permission of the military administration, to acquire plots of manor land in the villages and build trade and factory establishments with the right to own them as absolute property." [1].

The regulation provided the establishment of fees for the use of troops. That innovation made it possible to develop a network of agricultural processing and industrial construction in the Kuban region.

Based on the foregoing, we can conclude that the Regulation of 1862 amended the legal use of land relations in the Kuban region. That affected changes in the legal status of 
military lands. In fact, this institution was abolished by the creation of the Kuban Cossack army and the formation of an administrative-territorial unit with governing bodies. [5, P. 147].

The provision allowed the introduction of individual hereditary tenure without the permission of the community. So a legal basis was created for settling out of town and selfdetermination of settledness. On the basis of it, the established customary legal regulation of land relations among the Cossacks was radically changed. It was the beginning of the development of diverse forms of land relations in the Kuban region.

Summing up the parameters of the legal essence of the Regulation of 1862, as a normative act that developed the principles of legal regulation of land relations in the Kuban region, it should be noted that the Regulation of 1862 in a complete form individualized the land rights of both the Cossacks and their communities and total troops. The regulation exactly divided all Cossack military lands into three different types of land ownership: military, communal and private.

By the way, speaking about the evolution of land ownership in the Kuban region, it should be noted that quite significant changes occurred only in the second half of the XIXth century. The changes were greatly influenced by the peasant reform of 1861 carried out in the Caucasus region.

As for the legal regulation of land relations of the Kuban Cossacks in the second half of the XIXth-early XXth centuries, we came to the following conclusions. There were two trends in the legal registration of land relations in the Kuban Cossack army: conservatism of the communal order, on the one hand, and the consolidation of the privileges of the social elite, on the other. The decisive period of the transition to a new land tenure system was in the 60s of XIXth century. Within one decade the legal consolidation was realized by three forms of land ownership: military, communal and private.

$$
* * *
$$

1. Complete Collection of Laws of the Russian Empire. 2nd collection. Vol. XXVII. №. 38256.

2. Kudashev V. Historical information of the Kabardian people. Kiev: Tipo-lit. "C.V. Kulzhenko", 1913. Pp. 227-228.

3. Musheghyan S.V. Legal features of the formation of Cossack land ownership in the Kuban (late XVIIIthsecond half of the XIXth centuries) // Law and Politics, M.: NOTA BENE, 2007. №1. Pp. 110-114.

4. Mushegyan S.V. The legal personality of land users in the North Caucasus and Transcaucasia in the XIXth and early XXth centuries // Law and Politics, M.: NOTA BENE, 2009. №9. Pp. 1960-1963.

5. Mushegyan S.V., Semenova S.N. Legal regulation of land relations of the Cossacks, the mountain population, nonresident peasants in the Kuban in the second half of the nineteenth century // Social sphere of society: innovative development trends: collection of materials of the $\mathrm{V}$ International scientific and practical conf. "The social sphere of society: innovative development trends" (December 5, 2014); Institute of Economics and Management in Medicine and the Social Sphere. Krasnodar: Institute of Economics and Management in Medicine and the Social Sphere, 2015. Pp. 146-149.

6. Russian State Military Historical Archive. F. 330. Op. 61. D. 154. L. 43-47. 